\title{
Neuropeptides isotocin and arginine vasotocin in urophysis of three fish species
}

\author{
Magdalena Gozdowska • Marek Ślebioda • \\ Ewa Kulczykowska
}

Received: 9 August 2012/Accepted: 29 October 2012/Published online: 10 November 2012

(C) The Author(s) 2012. This article is published with open access at Springerlink.com

\begin{abstract}
In this study, for the first time, both neuropeptides isotocin (IT) and arginine vasotocin (AVT) have been identified and measured in urophysis, the neurohaemal organ of the caudal neurosecretory system of teleost fish. So far, AVT, but not IT, was quantified by radioimmunoassay (RIA) in urophysis of several fish species. We have used high-performance liquid chromatographic assay with fluorescence detection (HPLC-FL) preceded by solid-phase extraction (SPE) and liquid chromatography-electrospray ionization triple-quadrupole tandem mass spectrometry (LC-ESI MS/MS) technique to determine both neuropeptides in urophysis of three fish species. The efficiency of peptide's SPE extraction was 79-85\%. In HPLC-FL method, the limits of detection (LOD) and quantification (LOQ) were estimated as 1.0 and $3.4 \mathrm{pmol} / \mathrm{mL}$ for IT and 0.25 and $2.20 \mathrm{pmol} / \mathrm{mL}$ for AVT. In LC-MS/MS method, LOD and LOQ were estimated as 0.4 and $1.2 \mathrm{pmol} / \mathrm{mL}$ for IT and 0.06 and $0.2 \mathrm{pmol} / \mathrm{mL}$ for AVT. The chromatographic methods are good alternative for RIA, because enable to measure both nonapeptides simultaneously in one
\end{abstract}

M. Gozdowska · E. Kulczykowska ( ()

Department of Genetics and Marine Biotechnology, Institute of Oceanology of Polish Academy of Sciences, Powstańców Warszawy 55 St., 81-712 Sopot, Poland e-mail: ekulczykowska@iopan.gda.pl

M. Ślebioda

Perlan Technologies Sp. z.o.o, Puławska 303 St., 02-785 Warszawa, Poland sample. In round goby (Neogobius melanostomus), three-spined stickleback (Gasterosteus aculeatus) and sea bream (Sparus aurata), urophysial IT concentrations ranged between 0.056 and $0.678 \mathrm{pmol} / \mathrm{mg}$ tissue and AVT concentrations ranged between 0.0008 (or even below detection threshold) and $0.084 \mathrm{pmol} / \mathrm{mg}$ tissue.

Keywords Isotocin - Arginine vasotocin - Fish . High-performance liquid chromatography · Mass spectrometry · Urophysis

\section{Introduction}

In teleostean fish, neurones localized in the parvocellular and magnocellular nuclei of the preoptic area, synthesize nonapeptides, isotocin (IT) and arginine vasotocin (AVT). Neurones project both to the neurohypophysis, where neuropeptides are released to the circulation, and to multiple regions of the brain (Holmqvist and Ekström 1995; Saito et al. 2004). Circulating IT and AVT have well-defined roles in osmoregulation, cardiovascular responses and regulation of various hormones' release; their central actions consist in regulation of social and reproductive behaviour (Kulczykowska 2008). In fishes, there is also a unique caudal neurosecretory system (CNSS) (Fridberg and Bern 1968). The general morphology of CNSS parallels that of hypothalamo-neurohypophyseal system that is present in all vertebrate species. The 
ultrastructural characteristics of both systems are also strictly comparable. The CNSS consists of large magnocellular neurons-Dahlgren cells—located in the terminal vertebral segments of the spinal cord, which project axons to the urophysis, a neurohaemal organ in teleost fishes (Fridberg and Bern 1968). Fish caudal neurosecretory system was reviewed sufficiently by McCrohan et al. (2007) and Winter et al. (2000). It is well known that urophysis is a site of storage and release of peptides, that is, urotensin I (UI), urotensin II (UII), corticotropin-releasing factor (CRF) and parathyroid hormone-related protein (PTHrP) (Pearson et al. 1980; Lederis et al. 1982; Ingleton et al. 2002), which are synthesized by Dahlgren cells. Also, AVT-like immunoreactivity has been reported in urophysis of several fish species (Holden et al. 1979; Harding et al. 1997). To the authors' knowledge, IT has not been yet identified here.

In this study, for the first time, IT has been detected and measured in urophysis. Although AVT has been previously measured by RIA, it should be noted that there is the first study where both IT and AVT have been successfully quantified in urophysis. Herein, two different chromatographic techniques: high-performance liquid chromatography with fluorescence detection (HPLC-FL) and liquid chromatographyelectrospray ionization triple-quadrupole tandem mass spectrometry (LC-ESI MS/MS) have been used to measure both nonapeptides in samples taken from three fish species, round goby (Neogobius melanostomus), three-spined stickleback (Gasterosteus aculeatus) and sea bream (Sparus aurata). The benefit of using the chromatographic methods is that both IT and AVT are quantified simultaneously in the same sample.

\section{Materials and methods}

\section{Chemicals}

All chemicals were of analytical grade purity. Synthetic IT and AVT were purchased from BACHEM (Bubendorf, Switzerland), 4-fluoro-7-nitro-2,1,3-benzoxadiazole (NBD-F) and glacial acetic acid (AcOH) from Sigma-Aldrich (Steinheim, Switzerland), and trifluoroacetic acid (TFA) and HPLC-grade acetonitrile from J.T. Baker (Deventer, Netherlands). Ultra pure Milli-Q water was used throughout the work.
Animals and samples preparation

Round gobies (Neogobius melanostomus, 49-70 g) used in this study were caught in Gdansk Bay and three-spined sticklebacks (Gasterosteus aculeatus, 4.1-5 g) in Oliwski Potok in Gdansk, Poland, at the beginning of spawning season. Before sampling fishes were anesthetized in $0.5 \%(\mathrm{v} / \mathrm{v})$ 2-phenoxyethanol water solution. After transection of the spinal cord, the urophysis with six pre-terminal vertebras was removed and stored at $-70{ }^{\circ} \mathrm{C}$ prior to analysis. In round goby and stickleback, it was technically unfeasible to separate the urophysis from vertebras; therefore, the analysis was done in the whole sample. Immature sea breams (Sparus aurata, 200-250 g) were provided by Planta de Cultivos Marinos (C.A.S.E.M., Universidad de Cadiz, Puerto Real, Cadiz, Spain). Urophysis from sea bream was removed by Dr. Juan Miguel Mancera Romero (Universidad de Cadiz, Puerto Real, Cadiz, Spain) and sent on dry ice to our laboratory.

All samples were homogenized in $2 \mathrm{~mL}$ of water for 3 min using Silent Crusher M. homogenizer (Heidolph, Germany). Following homogenization, $10 \mu \mathrm{L}$ of acetic acid was added and the mixture was transferred to boiling water bath for $5 \mathrm{~min}$ and then centrifuged for $20 \mathrm{~min} 10,000 \mathrm{rpm}$ at $4{ }^{\circ} \mathrm{C}$. The supernatant was decanted and loaded onto previously conditioned ( $2 \mathrm{~mL} \mathrm{MeOH}, 1 \mathrm{~mL}$ water) SPE columns (STRATA-X, $30 \mathrm{mg} / 1 \mathrm{~mL}$, Phenomenex). Solidphase extraction (SPE) extraction was performed using Baker SPE 12G column Processor (J.T.Baker, Phillipsburg, USA). Water $(600 \mu \mathrm{L})$ then $0.1 \%$ TFA (trifluoroacetic acid) in $5 \%$ acetonitrile $(600 \mu \mathrm{L})$ was passed through the columns to wash away impurities. The peptides were eluted by $2 \times 600 \mu \mathrm{L}$ of $80 \%$ acetonitrile. The eluates were evaporated to dryness using Turbo Vap LV Evaporator (Caliper Life Science, USA). For further HPLC-FL and LC-MS/ MS analyses, the samples were re-dissolved in $40 \mu \mathrm{L}$ of $0.1 \%$ TFA and divided into two for possible repetition.

In order to verify the efficiency of extraction, the samples of pulled tissue supernatant were spiked with 7, 56 and $112 \mathrm{pmol} / \mathrm{mL}$ of standard IT and 10.5, 84 and $168 \mathrm{pmol} / \mathrm{mL}$ of standard AVT and each extraction was repeated three times. The extraction recovery of IT and AVT was estimated as 79-85\%. 
IT and AVT determination by HPLC-FL

Pre-column derivatization of IT and AVT in each of $20 \mu \mathrm{L}$ samples was performed using $2 \mu \mathrm{L}$ NBD-F (4-fluoro-7-nitro-2,1,3-benzoxadiazole) solution (30 mg NBD-F in $1 \mathrm{~mL}$ of acetonitrile) in mixture of $20 \mu \mathrm{L}$ phosphoric buffer $(0.2 \mathrm{M}, \mathrm{pH} 9.0)$ and $20 \mu \mathrm{L}$ acetonitrile. The solution was heated at $60{ }^{\circ} \mathrm{C}$ for $3 \mathrm{~min}$ in a dry-heating block and cooled down on ice. Next, $4 \mu \mathrm{L}$ of $1 \mathrm{M} \mathrm{HCl}$ was added to the mixture to terminate the reaction and inhibit high background resulting from hydrolysis of NBD-F excess.

Derivatized samples were measured with Agilent 1200 Series Quaternary HPLC System (Agilent Technologies, USA) equipped with a quaternary pump, autosampler, thermostated column compartment and fluorescent detector. Chromatographic separation was achieved on Agilent Zorbax Eclipse XDB-C18 column $(150 \mathrm{~mm} \times 4.6 \mathrm{~mm}$ I.D., $5 \mu \mathrm{m}$ particle size). Gradient elution system was applied for separation of derivatized peptides. The mobile phase consisted of solvent A $\left(0.1 \%\right.$ TFA in $\left.\mathrm{H}_{2} \mathrm{O}\right)$ and solvent B [0.1 \% TFA in acetonitrile: $\left.\mathrm{H}_{2} \mathrm{O}(3: 1)\right]$. A linear gradient was $45-80 \%$ of eluent $\mathrm{B}$ in $12 \mathrm{~min}$. Flow rate was set at $1 \mathrm{~mL} / \mathrm{min}$ and the column temperature at $20{ }^{\circ} \mathrm{C}$. Injection volume was $40 \mu \mathrm{L}$ (round goby and sea bream samples) or $66 \mu \mathrm{L}$ (threespined stickleback samples). Fluorescence detection was carried out at $530 \mathrm{~nm}$ with excitation at $470 \mathrm{~nm}$.

The peptides were quantified using external calibration curves. The synthetic IT was dissolved in $20 \%$ $(\mathrm{v} / \mathrm{v})$ acetic acid $(1 \mathrm{mg} / \mathrm{mL})$ and AVT in water $(1 \mathrm{mg} /$ $1 \mathrm{~mL})$. Both peptides were stored at $-20{ }^{\circ} \mathrm{C}$. Standard peptides at six different concentrations ranging from 0.250 to $252 \mathrm{pmol} / \mathrm{mL}$ were derivatized and injected onto HPLC. The calibration curve for IT and for AVT showed high linearity with correlation coefficient $R^{2}=0.9995$ and $R^{2}=0.9891$, respectively. The limit of detection (LOD) and quantification (LOQ) for IT and AVT in the urophysis' extracts could not be determined directly, since real IT- and AVT-free samples are not available. LOD was assessed as three times signal-to-noise and LOQ as ten times signal-tonoise using standard solutions; LOD for IT and AVT were 2.20 and $3.4 \mathrm{pmol} / \mathrm{mL}$, and LOQ for IT and AVT were 0.25 and $1.0 \mathrm{pmol} / \mathrm{mL}$, respectively.

To validate the method, precision of IT and AVT measurements were examined. The intra-day precision, expressed as relative standard deviation (RSD), was in the 5.3-8.2 \% range for IT and 6.9-7.95\% for AVT. The inter-day precision (RSD), evaluated by analysis of three replicate samples in three consequent days, was from 5.5 to $8.5 \%$ for IT and from 8.2 to $9.85 \%$ for AVT.

\section{IT and AVT determination by LC-ESI MS/MS}

The LC-ESI MS/MS analyses of IT and AVT were performed using Infinity 1290 System (Agilent Technologies, USA) coupled with triple-quadrupole mass spectrometer Agilent 6460A equipped with a JetStream ESI source. A JetStream ESI source was operated in positive ionization mode with capillary voltage of $3,500 \mathrm{~V}$, nozzle voltage of $500 \mathrm{~V}$, drying gas temperature of $300{ }^{\circ} \mathrm{C}$, gas flow of $5 \mathrm{~L} / \mathrm{min}$, nebulizer gas pressure of 45 psi, sheath gas temperature of $250{ }^{\circ} \mathrm{C}$ and sheath gas flow rate of $11 \mathrm{~L} / \mathrm{min}$.

Chromatographic separation was done using Agilent Zorbax Extend Plus C18 column $(2.1 \mathrm{~mm} \times$ $50 \mathrm{~mm}, 1.8 \mu \mathrm{m}$ particle). The mobile phase consisted of solvent $\mathrm{A}\left(0.1 \%\right.$ acetic acid in $\left.\mathrm{H}_{2} \mathrm{O}\right)$ and solvent $\mathrm{B}$ [0.1\% acetic acid in acetonitrile: $\mathrm{H}_{2} \mathrm{O}$ (3:1)]. A gradient elution was used starting from 5 to $30 \% \mathrm{~B}$ in $5.3 \mathrm{~min}$. The column was washed with $95 \% \mathrm{~B}$ for $1.5 \mathrm{~min}$ and then equilibrated for $4 \mathrm{~min}$ at starting conditions after each analysis. Flow rate of the mobile phase was set at $0.6 \mathrm{~mL} / \mathrm{min}$, and the column temperature was set at $20{ }^{\circ} \mathrm{C}$. The injection volume was $5 \mu \mathrm{L}$.

Detection of the peptides was performed by multiple reaction monitoring (MRM). The monitored mass transitions for IT were set at $\mathrm{m} / \mathrm{z} 483.7 \rightarrow 136.1$ (dwell time $100 \mathrm{~ms}$, fragmentor voltage $74 \mathrm{~V}$ and collision energy $53 \mathrm{~V}$ ). The monitored mass transitions for AVT were set at m/z 525.5 $\rightarrow 517.2$ (dwell time $100 \mathrm{~ms}$, fragmentor voltage $143 \mathrm{~V}$ and collision energy $9 \mathrm{~V}$ ).

Detection and quantification limits were estimated on the basis of signal-to-noise ratio as 0.4 and $1.2 \mathrm{pmol} / \mathrm{mL}$ for IT and 0.06 and $0.2 \mathrm{pmol} / \mathrm{mL}$ for AVT. Correlation coefficients of the calibration curves constructed using standard of the peptides were $R^{2}=0.9867$ for IT and $R^{2}=0.9867$ for AVT.

\section{Results and discussion}

It has been established that Dahlgren cells produce a wide variety of peptides (Pearson et al. 1980; Lederis 
et al. 1982; Ingleton et al. 2002); however, so far, IT has never been detected in urophysis. Determination of bioactive nonapeptides, IT and AVT, after their dissociation from non-covalent complex, in biological samples, is a big challenge due to their low concentrations and fast decomposition in tissues. In brain, vasopressin and oxytocin (mammalian homologues of AVT and IT), and AVT released at synaptic sites are subjected to rapid degradation by aminopeptidase enzymes (Wang et al. 1983; Burbach and Lebouille 1983; Stark et al. 1989; Burbach and Wiegant 1990). For instance, in vivo studies revealed a half-life below $1 \mathrm{~min}$ for vasopressin after its administration into limbic brain area of rat (Stark et al. 1989). Highperformance liquid chromatographic (HPLC) assays elaborated in our laboratory (Kulczykowska 1995; Gozdowska and Kulczykowska 2004; Gozdowska et al. 2006; Kleszczyńska et al. 2006) enabled to measure free AVT and IT in plasma, pituitary and brain, but were ineffective for IT in urophysis. In this study, for the first time, IT was detected and measured in urophysis. Simultaneously, in the same sample, AVT was quantified.

Herein, we have provided two different chromatographic assays devoted to IT measurement in urophysis that turned out to be useful also for AVT measurement in the same sample. The HPLC-FL proceeded by SPE and pre-column derivatization using NBD-F (4-fluoro-7-nitro-2,1,3-benzoxadiazole) as fluorescent tag is significantly modified version of our previous method. Typical HPLC chromatogram for urophysial IT and AVT is shown in Fig. 1. The method has been applied to determine IT and AVT in samples taken from round goby and three-spined stickleback. The LC-ESI MS/MS analysis was performed in round goby, three-spined stickleback and sea bream samples. An example of LC-ESI MS/MS chromatogram for urophysial neuropeptides is shown in Fig. 2. Although HPLC-FL and LC-ESIMS/MS analyses, for obvious reasons have not been applied in the same sample, they have given comparable results (Table 1). The neuropeptides' concentrations are expressed as pmol per gland and pmol per mg tissue (Table 1) for easier comparison with other published data. As was mentioned before, in round goby and stickleback, it is technically unfeasible to separate the urophysis from vertebras. Consequently, in these two species, the whole sample, that is, urophysis with six pre-terminal vertebras, has been used for analysis and (a)

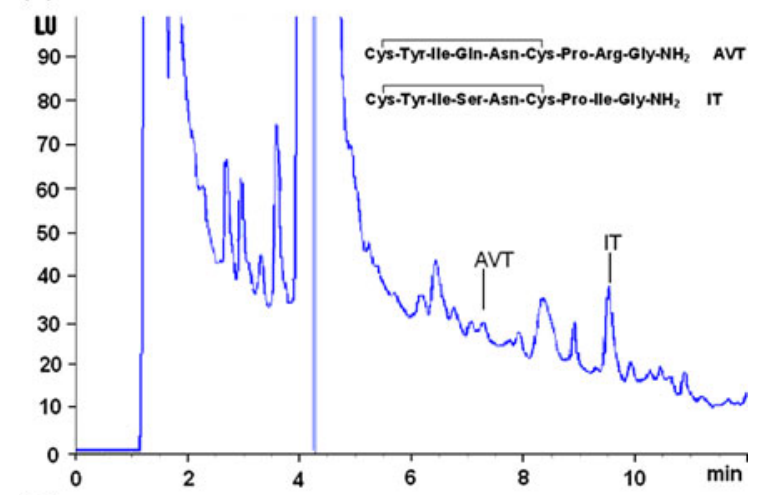

(b)

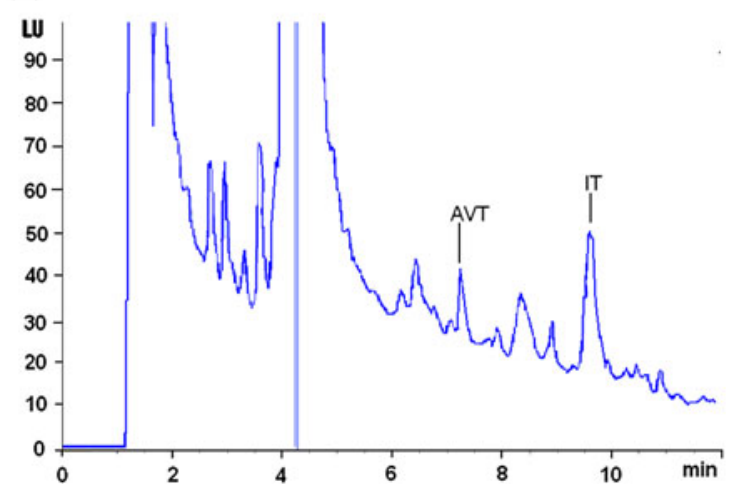

Fig. 1 Representative HPLC-FL chromatograms of a urophysial sample of round goby and $\mathbf{b}$ the same sample spiked with standard AVT $(6.6 \mathrm{pmol} / \mathrm{mL})$ and IT $(6.8 \mathrm{pmol} / \mathrm{mL})$. Chromatographic conditions: Agilent Zorbax Eclipse XDB-C18 column $(150 \mathrm{~mm} \times 4.6 \mathrm{~mm}$ I.D., $5 \mu \mathrm{m}$ particle); elution: solvent A $\left(0.1 \%\right.$ TFA in $\left.\mathrm{H}_{2} \mathrm{O}\right)$, solvent $\mathrm{B}$ [0.1\% TFA in acetonitrile : $\mathrm{H}_{2} \mathrm{O}(3: 1)$ ], linear gradient $45-80 \%$ of eluent $\mathrm{B}$ in $12 \mathrm{~min}$; flow rate $1 \mathrm{~mL} / \mathrm{min}$; column temperature $20{ }^{\circ} \mathrm{C}$; injection volume $40 \mu \mathrm{L}$; detection: FL, excitation $470 \mathrm{~nm}$, emission $530 \mathrm{~nm}$

calculation. On the other hand, urophysis in sea bream is easy to separate from adjacent tissues, and thus genuine urophysis has been used for analysis and calculation. IT concentrations in three fish species are between 0.056 and $0.678 \mathrm{pmol} / \mathrm{mg}$ tissue. There is no other information on IT in urophysis, therefore, out of necessity the only available data, that is, brain, pituitary and plasma IT levels are cited here for comparison. Thus far a wide range of IT concentrations has been measured in various fish species, and IT concentrations measured in our study are within the range. Plasma IT in freshwater rainbow trout (Oncorhynchus mykiss) subjected to osmotic or disturbance stresses ranges from 0.05 to $0.10 \mathrm{pmol} / \mathrm{mL}$ 


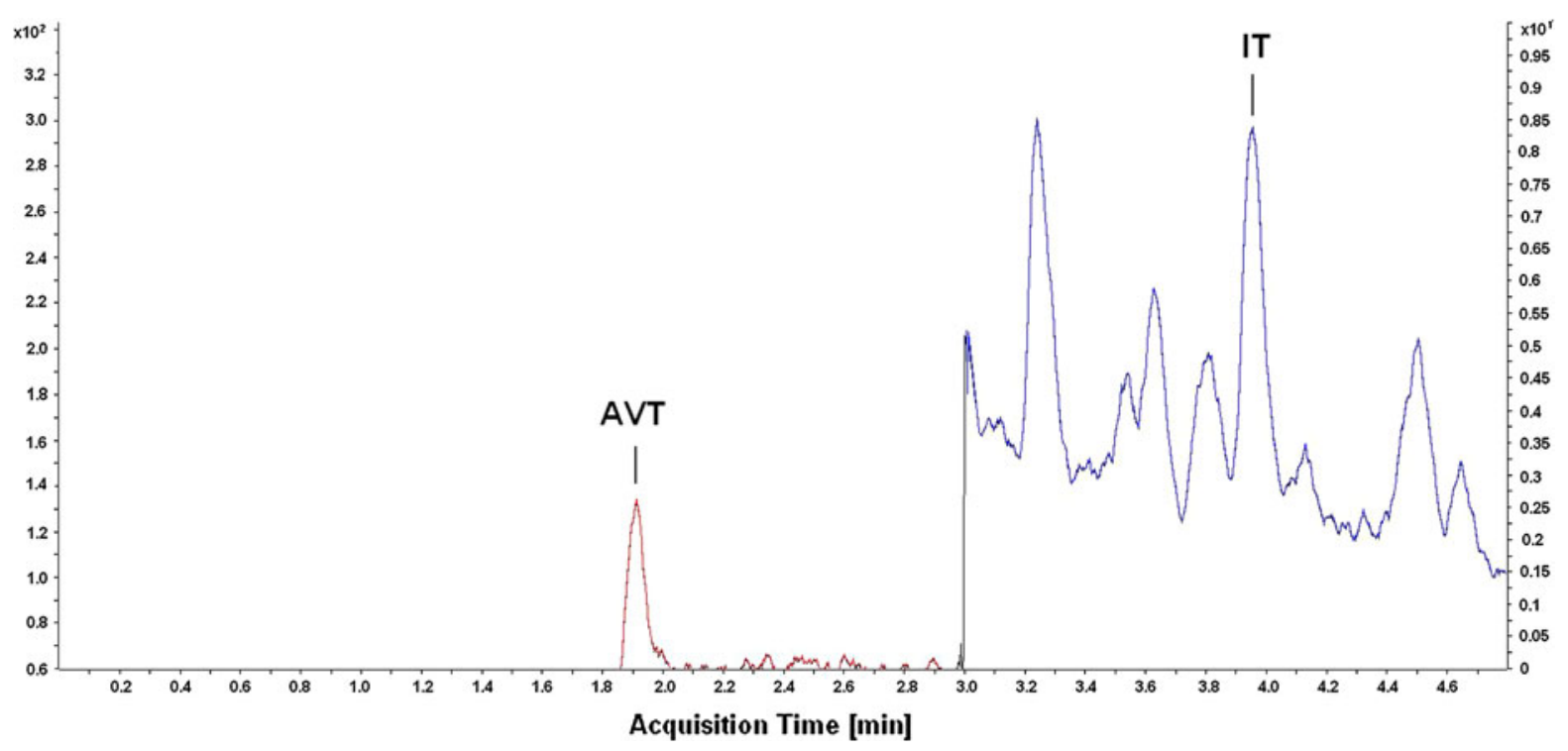

Fig. 2 Representative LC-ESI MS/MS MRM (multi reaction monitoring) chromatogram of urophysial sample of round goby. Chromatographic conditions: Agilent Zorbax Extend Plus C18 column $(50 \mathrm{~mm} \times 2.1 \mathrm{~mm}$ I.D., $1.8 \mu \mathrm{m}$ particle); elution: solvent $\mathrm{A}\left(0.1 \%\right.$ acetic acid in $\left.\mathrm{H}_{2} \mathrm{O}\right)$, solvent $\mathrm{B}[0.1 \%$ acetic

(Kulczykowska 1997, 2001). Diurnal variations of plasma IT in this species are between 0.04 and $0.08 \mathrm{pmol} / \mathrm{mL}$ (Kulczykowska and Stolarski 1996; Kulczykowska 1999). In rainbow trout, pituitary contents of IT during the day are between 0.25 and $0.85 \mathrm{pmol} / \mu \mathrm{g}$ protein (Rodríguez-Illamola et al. 2011). In sea bream (Sparus aurata) exposed to different photoperiods, concentrations of IT in the brain change from 0.1 to $1.0 \mathrm{pmol} / \mathrm{mg}$ tissue (Gozdowska et al. 2006). Levels of the peptide in pituitary of sea bream subjected to different stresses are between 550 and $700 \mathrm{pmol} /$ pituitary (Kleszczyńska et al. 2006). In three-spined stickleback, brain levels of IT range from 0.5 to $10 \mathrm{pmol} / \mathrm{mg}$ tissue (Gozdowska et al. 2006; Kleszczyńska et al. 2007, 2012). In Mozambique tilapia (Oreochromis mossambicus), IT levels range from 1.5 to $75 \mathrm{pmol} / \mathrm{mg}$ tissue in macro-dissected brain areas, that is, olfactory bulbs, telencephalon, diencephalons, optic tectum, cerebellum, hindbrain and pituitary (Almeida et al. 2012).

In our studies, AVT levels measured by chromatographic techniques that are between 0.0018 (or even below detection threshold—nd) and $0.84 \mathrm{pmol} / \mathrm{gland}$, or 0.0006 (or nd) and $0.0015 \mathrm{pmol} / \mathrm{mg}$ tissue are consistent with levels measured by RIA in other studies. The AVT concentrations in flounder's acid in acetonitrile: $\mathrm{H}_{2} \mathrm{O}(3: 1)$ ], a gradient elution was used starting from 5 to $30 \% \mathrm{~B}$ in $5.3 \mathrm{~min}$; flow rate $0.6 \mathrm{~mL} / \mathrm{min}$; column temperature $20{ }^{\circ} \mathrm{C}$; injection volume $5 \mu \mathrm{L}$; the monitored mass transitions for AVT were set at $\mathrm{m} / \mathrm{z} 525.5 \rightarrow 517.2$ and for IT were set at $\mathrm{m} / \mathrm{z} 483.7 \rightarrow 136.1$

(Platichthys flesus), silver eel's (Anguilla anguilla), long-spined bullhead's (Cottus bubalis) and fivebearded rockling's (Onos mustela) urophysis ranged from 0.096 to $0.276 \mathrm{pmol} / \mathrm{gland}$ (Holden et al. 1979; Harding et al. 1997).

As has been shown in our study, AVT concentration in urophysis is significantly lower than that of IT, that is, concentration difference is even over 2 orders (Table 1).

So far, it has been accepted that the main sources of AVT and IT are neurones localized in the parvocellular and magnocellular nuclei of the preoptic area, and neurohypophysis is the main site of neuropeptides release into circulation. There is still a doubt whether CNSS contributes significantly to the peripheral pool of the hormones. Moreover, a question arises whether AVT and IT measured in urophysis are produced in Dahlgren cells or are transported to CNSS by axons projected from the brain. It is established that the CNSS receives descending serotonergic, monoaminergic and peptidergic inputs, mainly from the hindbrain (Audet and Chevalier 1981; Miller and Kriebel 1986; Cohen and Kriebel 1989). Saito et al. (2004) found abundant IT and scarce AVT fibres in the anterior end of spinal cord in rainbow trout (Oncorhynchus mykiss). It may explain significantly 
Table 1 IT and AVT concentrations in round goby (Neogobius melanostomus) and threespined stickleback (Gasterosteus aculeatus) samples-urophysis with six preterminal vertebras, and in sea bream (Sparus aurata) - urophysis, determined by HPLC-FL and LC-ESI MS/MS

\begin{tabular}{|c|c|c|c|c|c|}
\hline $\begin{array}{l}\text { Species } \\
\text { Fish no. }\end{array}$ & $\begin{array}{l}\text { IT } \\
\text { (pmol per } \\
\text { gland) }\end{array}$ & $\begin{array}{l}\text { IT } \\
\text { (pmol } \mathrm{mg}^{-1} \\
\text { tissue) }\end{array}$ & $\begin{array}{l}\text { AVT } \\
\text { (pmol per } \\
\text { gland) }\end{array}$ & $\begin{array}{l}\text { AVT } \\
\text { (pmol mg } \\
\text { tissue) }\end{array}$ & Method \\
\hline \multicolumn{6}{|c|}{ Neogobius melanostomus } \\
\hline 1 & 6.63 & 0.095 & 0.59 & 0.0084 & HPLC-FL \\
\hline 2 & 5.85 & 0.096 & 0.84 & 0.014 & HPLC-FL \\
\hline 3 & 3.98 & 0.073 & 0.80 & 0.015 & HPLC-FL \\
\hline 4 & 3.769 & 0.056 & 0.348 & 0.0052 & $\begin{array}{c}\text { LC-MS/ } \\
\text { MS }\end{array}$ \\
\hline 5 & 5.863 & 0.11 & 0.068 & 0.0012 & $\begin{array}{c}\text { LC-MS/ } \\
\text { MS }\end{array}$ \\
\hline 6 & 4.768 & 0.095 & 0.059 & 0.0012 & $\begin{array}{c}\text { LC-MS/ } \\
\text { MS }\end{array}$ \\
\hline \multicolumn{6}{|c|}{ Gasterosteus aculeatus } \\
\hline 1 & 3.39 & 0.678 & 0.040 & 0.008 & HPLC-FL \\
\hline 2 & 2.23 & 0.496 & 0.038 & 0.008 & HPLC-FL \\
\hline 3 & 2.89 & 0.578 & 0.052 & 0.0104 & HPLC-FL \\
\hline 4 & 1.89 & 0.420 & nd & nd & HPLC-FL \\
\hline 5 & 1.52 & 0.473 & nd & nd & HPLC-FL \\
\hline 6 & 1.252 & 0.313 & 0.014 & 0.0034 & $\begin{array}{c}\text { LC-MS/ } \\
\text { MS }\end{array}$ \\
\hline 7 & 1.463 & 0.363 & nd & nd & $\begin{array}{c}\text { LC-MS/ } \\
\text { MS }\end{array}$ \\
\hline \multicolumn{6}{|c|}{ Sparus aurata } \\
\hline 1 & 1.271 & 0.152 & nd & nd & $\begin{array}{c}\text { LC-MS/ } \\
\text { MS }\end{array}$ \\
\hline 2 & 0.349 & 0.179 & nd & nd & $\begin{array}{c}\text { LC-MS/ } \\
\text { MS }\end{array}$ \\
\hline 3 & 1.098 & 0.195 & 0.0093 & 0.0017 & $\begin{array}{l}\text { LC-MS/ } \\
\text { MS }\end{array}$ \\
\hline 4 & 0.310 & 0.165 & 0.0056 & 0.0028 & $\begin{array}{c}\text { LC-MS/ } \\
\text { MS }\end{array}$ \\
\hline 5 & 0.214 & 0.074 & 0.0018 & 0.0006 & $\begin{array}{l}\text { LC-MS/ } \\
\text { MS }\end{array}$ \\
\hline
\end{tabular}

nd Not detected

M.Gozdowska. We would like to thank Dr. Juan Miguel Mancera Romero for providing us with sea bream samples.

Open Access This article is distributed under the terms of the Creative Commons Attribution License which permits any use, distribution, and reproduction in any medium, provided the original author(s) and the source are credited.

\section{References}

Almeida O, Gozdowska M, Kulczykowska E, Oliveira RF (2012) Brain levels of arginine-vasotocin and isotocin in dominant and subordinate males of a cichlid fish. Horm Behav 61(2):212-217 
Audet C, Chevalier G (1981) Monoaminergic innervation of the caudal neurosecretory system of the brook trout Salvelinus fontinalis in relation to osmotic stimulation. Gen Comp Endocrinol 45(2):189-203

Burbach JPH, Lebouille JLM (1983) Proteolytic conversion of arginine-vasopressin and oxytocin by brain synaptic membranes. J Biol Chem 258(3):1487-1494

Burbach JPH, Wiegant VM (1990) Gene expression, biosynthesis and processing of pro-opiomelanocortin peptides and vasopressin. In: De Honorary ied (ed) Neuropeptides basics and perspectives. Elsevier Science Publishers, B.V. Biomedical Devision, pp 45-103

Cohen SL, Kriebel RM (1989) Brainstem location of serotonin neurons projecting to the caudal neurosecretory complex. Brain Res Bull 22(3):481-487

Fridberg G, Bern HA (1968) The urophysis and the caudal neurosecretory system of fishes. Biol Rev 43(2):75-199

Gozdowska M, Kulczykowska E (2004) Determination of arginine-vasotocin and isotocin in fish plasma with solidphase extraction and fluorescence derivatization followed by high-performance liquid chromatography. J Chromatogr B 807:229-233

Gozdowska M, Kleszczyńska A, Sokołowska E, Kulczykowska E (2006) Arginine vasotocin (AVT) and isotocin in fish brain: diurnal and seasonal variations. Comp Biochem Physiol B 143:330-334

Harding KE, Warne JM, Hyodo S, Balment RJ (1997) Pituitary and plasma AVT content in the flounder (Platichthys flesus). Fish Physiol Biochem 17(1-6):357-362

Holden FC, Schroeder MD, Guerne JM, Vivien-Roels B (1979) A preliminary comparative immunohistochemical, radioimmunological, and biological study of arginine vasotocin (AVT) in the pineal gland and urophysis of some teleostei. Gen Comp Endocrinol 37(1):15-25

Holmqvist BI, Ekström P (1995) Hypophysiotrophic systems in the brain of the Atlantic salmon. Neuronal innervation of the pituitary and the origin of pituitary dopamine and nonapeptides identified by means of combined carbocyanine tract tracing and immunocytochemistry. J Chem Neuroanat 8:125-145

Ingleton PM, Bendell LA, Flanagan JA, Teitsma C, Balment RJ (2002) Calcium-sensing receptors and parathyroid hormone-related protein in the caudal neurosecretory system of the flounder (Platichthys flesus). J Anat 200(5):487-497

Kleszczyńska A, Vargas-Chacoff L, Gozdowska M, Kalamarz H, Martínez-Rodríguez G, Mancera JM, Kulczykowska E (2006) Arginine vasotocin, isotocin and melatonin responses following acclimation of gilthead sea bream (Sparus aurata) to different environmental salinities. Comp Biochem Physiol A 145:268-273

Kleszczyńska A, Dumont E, Cornelis R, Gozdowska M, Kulczykowska E, Sandra P (2007) Determination of the neuropeptides arginine vasotocin and isotocin in brains of three-spined sticklebacks (Gasterosteus aculeatus) by offline solid phase extraction-liquid chromatography-electrospray tandem mass spectrometry. J Chromatogr A 1150: 290-294

Kleszczyńska A, Sokołowska E, Kulczykowska E (2012) Variation in brain arginine vasotocin (AVT) and isotocin (IT) levels with reproductive stage and social status in males of three-spined stickleback (Gasterosteus aculeatus). Gen Comp Endocrinol 175:290-296
Kulczykowska E (1995) Solid-phase extraction of arginine vasotocin and isotocin in fish samples and subsequent gradient reversed-phase high-performance liquid chromatographic separation. J Chromatogr B 673:289-293

Kulczykowska E (1997) Response of circulating arginine vasotocin and isotocin to rapid osmotic challenge in rainbow trout. Comp Biochem Physiol A 118(3):773-778

Kulczykowska E (1999) Diel changes in plasma arginine vasotocin, isotocin and melatonin in rainbow trout $(\mathrm{On}$ corhynchus mykiss). Fish Physiol Biochem 21:141-146

Kulczykowska E (2001) Responses of circulating arginine vasotocin, isotocin and melatonin to osmotic and disturbance stress in rainbow trout (Oncorhynchus mykiss). Fish Physiol Biochem 24:201-206

Kulczykowska E (2008) Arginine vasotocin and isotocin as multifunctional hormones, neurotransmitters and neuromodulators in fish. In: Munoz-Cueto JA, Mancera JM, Martínez-Rodriguez G (eds) Avances en Endocrinología Comparada Servicio de Publicaciones, vol IV. Universidad de Cádiz, Spain, pp 41-47

Kulczykowska E, Stolarski J (1996) Diurnal changes in plasma arginine vasotocin and isotocin in rainbow trout adapted to fresh water and brackish Baltic water. Gen Comp Endocrinol 104:197-202

Lederis K, Letter A, McMaster D, Moore G, Schlesinger D (1982) Complete amino acid sequence of urotensin I, a hypotensive and corticotropin-releasing neuropeptide from Catostomus. Science 218(4568):162-165

McCrohan CR, Lu W, Brierley MJ, Dow L, Balment RJ (2007) Fish caudal neurosecretory system: a model for the study of neuroendocrine secretion. Gen Comp Endocrinol 153(1-3):243-250

Miller KE, Kriebel RM (1986) Peptidergic innervation of caudal neurosecretory neurons. Gen Comp Endocrinol 64(3): 396-400

Pearson D, Shively JE, Clark BR, Geschwind II, Barkley M, Nishioka RS, Bern HA (1980) Urotensin II: a somatostatinlike peptide in the caudal neurosecretory system of fishes. Proc Natl Acad Sci USA 77(8):5021-5024

Rodríguez-Illamola A, López Patiño MA, Soengas JL, Ceinos RM, Míguez JM (2011) Diurnal rhythms in hypothalamic/ pituitary AVT synthesis and secretion in rainbow trout: evidence for a circadian regulation. Gen Comp Endocrinol 170(3):541-549

Saito D, Komatsuda M, Urano A (2004) Functional organization of preoptic vasotocin and isotocin neurons in the brain of rainbow trout: central and neurohypophysial projections of single neurons. Neuroscience 124:973-984

Stark H, Burbach JPH, Van der Kleij AAM, De Wied D (1989) In vivo conversion of vasopressin after microinjection into limbic brain areas of rats. Peptides 10:717-720

Wang X-Ch, Burbach JPH, Verhoef JC, De Wied D (1983) Proteolytic conversion of arginine-vasotocin by synaptic membranes from rat and chicken brain. Brain Res 275: $83-90$

Winter MJ, Ashworth A, Bond H, Brierley MJ, McCrohan CR, Balment RJ (2000) The caudal neurosecretory system: control and function of a novel neuroendocrine system in fish. Biochem Cell Biol 78(3):193-203 